\title{
Biodiversitas Kumbang Koprofagus di Lahan Pertanian Organik dan Non-organik
}

\section{Biodiversity of Coprophagous Beetles in Organic and Non- organic Farms}

\author{
HANNA LATIFA ${ }^{1}$, TRI ATMOWIDI ${ }^{*}$, WORO A NOERDJITO ${ }^{2}$ \\ 'Departemen Biologi, Fakultas Matematika dan Ilmu Pengetahuan Alam, Institut Pertanian Bogor, \\ Kampus IPB Dramaga, Bogor 16680 \\ ${ }^{2}$ Laboratorium Entomologi, Divisi Zoologi, Pusat Penelitian Biologi-LIPI, Cibinong, Bogor 16911
}

Diterima 18 Juni 2019/Disetujui 14 Agustus 2019

\begin{abstract}
Coprophagous beetle has important role in decomposition of organic materials. This research aimed to study and analyze the diversity and abundance of coprophagous beetles in organic and non-organic farms. Coprophagous beetles were collected in organic farm of Bina Sarana Bakti and non-organic farm of Seruni in Cisarua, West Java. In each location, twenty dung traps were set up in corn plants, carrot plants, cabbage plants, and onion plants. Totally, 15 species (610 individuals) of coprophagous beetles belonging to two families i.e Scarabaeidae and Aphodiidae were collected. Coprophagous beetles in organic farms ( 389 individuals, 13 species) more divers than that in non-organic farms (221 individuals, 10 species). There was no dominant species in both of locations $(C<0.5)$. The most dominant species in organic farm was Copris reflexus (49\%) and in non-organic farm was Onthopagus pauper (52\%). Beetles similarity in organic and non-organic farm was $67 \%$.
\end{abstract}

Key words: Coprophagous beetles, organic farm, non-organic farm

\section{PENDAHULUAN}

Kumbang termasuk ordo Coleoptera yang dibedakan dengan ordo lain pada kelas Insecta berdasarkan adanya sepasang sayap depan yang keras (elytra) sebagai pelindung dari sayap belakang yang tipis dan lunak. Kumbang koprofagus dibedakan dengan kumbang lainnya berdasarkan bentuk tubuhnya yang cembung, bulat telur, atau memanjang, tarsi 5 ruas, antena 8-11 ruas, tiga ruas terakhir antena umumnya membesar membentuk gada dengan ujung padat, tibia pasangan tungkai depan membesar dengan bagian pinggir luar bergerigi atau berlekuk (Boror et al. 1989).

Kumbang koprofagus dibagi menjadi tiga kelompok berdasarkan perilakunya, yaitu tunnelers, dwellers, dan rollers. Kumbang tunnelers membawa kotoran ke dalam terowongan (tunnel) yang dibuatnya. Kotoran digunakan sebagai bahan pakan dan tempat meletakkan telur. Contoh spesies kumbang tunnelers adalah Phanaeus vindex dan Onthopagus sp. Kumbang dwellers memakan kotoran dan meletakkan telur di atas permukaan atau dekat dengan kotoran. Kumbang

*Penulis korespondensi:

E-mail: atmowidi@apps.ipb.ac.id koprofagus yang termasuk $d$ wellers adalah Aphodius sp. Kumbang rollers (Canthon sp.) membuat gumpalan bola dari kotoran yang akan dibawa ke sarang yang jauh dari asal kotoran. Kumbang rollers dapat meningkatkan kesuburan tanah dengan meningkatkan kandungan zat organik tanah dan mengurangi polusi dari limbah organik (Bertone et al. 2004).

Studi tentang kumbang koprofagus di Indonesia masih sangat terbatas, terutama di lahan pertanian. Krikken dan Huijbregts (2008) melaporkan di Taman Nasional Dumoga-Bone, Sulawesi Utara terkoleksi 39 spesies Scarabaeidae, 77\% diantaranya adalah genus Onthophagus dan spesies lainnya anggota famili Aphodiidae (4 spesies), Geotrupidae (2 spesies), Hybosoridae (1 spesies), dan Silphidae (4 spesies). Kahono dan Setiadi (2007) mengoleksi 28 spesies kumbang koprofagus di Taman Nasional Gede Pangrango, yang terdiri dari genus Onthopagus (21 spesies), Copris (3 spesies), Paragymnopleurus (2 spesies), Catharsius (1 spesies), dan Phacosoma (1 spesies). Kumbang Onthopagus merupakan genus yang mempunyai keanekaragaman tertinggi. Noerdjito (2009) mengoleksi 15 spesies kumbang kotoran di Taman Nasional Gunung Ciremai, Jawa Barat. 
Studi keanekaragaman kumbang koprofagus di lahan pertanian perlu dilakukan mengingat peran kumbang koprofagus dapat meningkatkan kesuburan tanah. Hanski dan Krikken (1991) melaporkan kumbang koprofagus merupakan dekomposer penting terkait dengan siklus nutrisi, penyebar benih, dan sebagai predator lalat. Kumbang koprofagus di lahan pertanian dapat dijadikan sebagai indikator kesuburan tanah (Andresen 2001). Penggunaan pupuk dan insektisida kimia pada lahan pertanian non-organik dapat mengganggu keseimbangan alam dan diduga berpengaruh pada keanekaragaman dan kelimpahan spesies kumbang koprofagus. Berbeda dengan lahan pertanian non-organik, lahan pertanian organik tidak menggunakan bahan kimia dalam kegiatan pengolahan lahan maupun dalam pengendalian hama, sehingga diduga jumlah individu dan spesies kumbang koprofagus lebih banyak.

Keanekaragaman spesies kumbang koprofagus dipengaruhi oleh berbagai faktor lingkungan, terutama tipe vegetasi, tanah, dan kotoran (Davis et al. 2001). Doube (1983) melaporkan bentuk kanopi tumbuhan dan tipe tanah juga berpengaruh terhadap spesies dan aktivitas kumbang koprofagus. Keberadaan kumbang koprofagus dipengaruhi oleh ketinggian habitat, kondisi habitat, dan struktur komunitas, terutama dari hewan vertebrata yang ada di habitat tersebut (Noerdjito 2009). Penelitian ini bertujuan untuk mengukur dan menganalisis keanekaragaman dan kelimpahan kumbang koprofagus di lahan pertanian organik dan non-organik.

\section{BAHAN DAN METODE}

Koleksi kumbang. Kumbang dikoleksi dengan menggunakan dung trap. Dung trap berupa kotoran segar manusia seukuran ibu jari yang dibungkus dengan kain kasa dan digantung setinggi $3 \mathrm{~cm}$ di atas wadah pengumpul (volume $400 \mathrm{ml}$ ). Sepertiga dari wadah pengumpul diisi cairan preservasi dengan komposisi 1 liter air ditambahkan 3 sendok makan sabun cair dan 3 sendok makan garam (Kahono dan Setiadi 2007). Dung trap dipasang pada pertanaman jagung, wortel, bawang daun, dan kol dengan luasan sekitar $600 \mathrm{~m}^{2}$ yang ada di lahan organik dan non-organik. Pada setiap pertanaman, dipasang 5 dung trap selama 72 jam dan sampel kumbang diambil setiap 24 jam. Di setiap lokasi, pengambilan sampel kumbang dilakukan dengan 3 ulangan. Pengukuran data lingkungan, yaitu curah hujan, suhu, kelembaban, dan kondisi tanah dilakukan setiap hari selama pengoleksian kumbang.

Preservasi dan identifikasi spesimen kumbang. Pengawetan spesimen kumbang dilakukan secara basah dan kering. Pengawetan basah dilakukan dengan merendam spesimen kumbang dalam alkohol 70\%. Pengawetan kering dilakukan dengan mengoven kumbang selama 7 hari pada suhu $40^{\circ} \mathrm{C}$. Sebelumnya, kumbang dipin dan diberi label, nomor, dan keterangan tempat pengambilan sampel. Spesimen kumbang selanjutnya disimpan dalam kotak serangga. Identifikasi kumbang berdasarkan Borror et al. (1989) sampai tingkat famili dan Arrow (1991), Balthasar (1963) sampai tingkat spesies. Spesimen kumbang juga diverifikasi dengan membandingkan dengan spesimen acuan koleksi Museum Zoologicum Bogoriense (MZB) LIPI, Cibinong, Bogor.

Analisis Data. Kumbang yang telah diidentifikasi selanjutnya dideskripsi. Data kumbang dianalisis dengan menghitung indeks keanekaragaman Shannon $(\mathrm{H})$, evennes atau kemerataan Shannon (E), Dominansi (C), dan Similaritas Sorensen kuantitatif(Is) (Marguran 1988), dengan rumus sebagai berikut:

$$
\begin{aligned}
& \mathrm{H}^{\prime}=-\Sigma \mathrm{PilnPi}^{\prime} \\
& \mathrm{E}=\frac{\mathrm{H}^{\prime}}{\ln \mathrm{S}} \\
& \mathrm{C}=\Sigma \mathrm{Pi}^{2} \\
& \mathrm{IS}=\frac{2 \mathrm{jn}}{(\mathrm{aN}+\mathrm{bN})}
\end{aligned}
$$

Keterangan:

$$
\begin{aligned}
\mathrm{Pi} & =\frac{\mathrm{ni}}{\mathrm{N}} \\
\mathrm{ni} & =\text { total individu spesies } \mathrm{i} \\
\mathrm{N} & =\text { total individu } \\
\mathrm{S}= & \text { total spesies } \\
\mathrm{jn}= & \text { total individu yang jumlahnya lebih sedikit dari } \\
& \text { kedua lokasi } \\
\mathrm{aN} & =\text { total individu di lokasi a } \\
\mathrm{bN} & =\text { total individu di lokasi } \mathrm{b}
\end{aligned}
$$

\section{HASIL}

Lahan pertanian organik Bina Sarana Bakti dan lahan non-organik Seruni yang digunakan sebagai lokasi pengambilan sampel kumbang terletak di Kecamatan Cisarua, Jawa Barat pada ketinggian 800-1000 mdpl. Kedua lahan beriklim tropis basah dengan suhu udara berkisar antara $23-25^{\circ} \mathrm{C}$. Lahan pertanian Bina Sarana Bakti terletak di kawasan Cisarua (6 ${ }^{\circ} 41^{\prime} 17.16^{\prime \prime S} 106^{\circ} 56^{\prime} 59.86$ "E) merupakan lahan pertanian organik yang menggunakan bahan organik dalam semua tahapan praktik pertaniannya. Pupuk yang digunakan di lahan pertanian organik berupa pupuk kotoran ayam yang telah melalui proses pengomposan. Insektisida yang digunakan terbuat dari bahan alami seperti siung bawang putih, daun sirsak, dan bunga tagetes. Pemberian insektisida dilakukan pada awal penanaman dan dilanjutkan berdasarkan pengamatan ada atau tidaknya hama. 
Lahan pertanian non-organik Seruni terletak di kawasan Cisarua (6 ${ }^{\circ} 41^{\prime} 54.47^{\prime \prime} \mathrm{S} 106^{\circ} 57^{\prime} 10.06$ 'E). Lahan pertanian ini menggunakan bahan kimia sebagai bahan penunjang dalam praktik pertaniannya. Bahan kimia digunakan dalam pemupukan dan penyemprotan hama. Pupuk dasar yang digunakan adalah pupuk dari kotoran sapi, sedangkan pupuk kimia tambahan berupa kristal atau cairan yang disemprotkan. Penggunaan insektisida dilakukan dengan dosis dan jenis yang berbeda, tergantung spesies tanaman dan tingkat infeksi hama.

Suhu udara rata-rata di lahan pertanian organik sebesar $26.83^{\circ} \mathrm{C}$ dan di lahan pertanian non-organik sebesar $25.11^{\circ} \mathrm{C}$. Intensitas cahaya dan kelembaban di lahan organik adalah 14.1467 lux dan $63.67 \%$ dan di lahan non-organik sebesar 1408.67 lux dan $64.23 \%$. Keasaman tanah di lahan organik sebesar 7 dan di lahan non-organik sebesar 6.6 (Tabel 1).

Selama pengambilan sampel, di lahan pertanian organik dan non-organik didapatkan 610 individu kumbang koprofagus yang termasuk dalam 2 famili, yaitu Scarabaeidae (subfamili Coprinae) dan famili Aphodiidae (subfamili Aphodinae) (Tabel 2). Dari dua tipe lahan pertanian tersebut didapatkan 15 spesies kumbang (Gambar 1). Nilai keanekaragaman tertinggi di lahan organik ditemukan pada pertanaman kol sebesar 1.66 dan nilai terendah di lahan non-organik pada pertanaman kol sebesar 0.85. Di lahan pertanian organik didapatkan 389 individu (13 spesies), sedangkan di lahan non organik didapatkan 221 individu (10 spesies). Jumlah individu terbanyak pada pertanaman jagung di kedua lahan, organik (127 individu) dan non-organik (72 individu). Jumlah individu terendah pada pertanaman bawang daun di kedua lahan, organik (74 individu) dan non-organik (28 individu) (Tabel 2). Kesamaan spesies kumbang di lahan pertanian organik dan non-organik sebesar $67 \%$. Kesamaan terbesar $89 \%$ didapatkan pada pertanaman jagung. Pada pertanaman wortel, similaritas kumbang sebesar $64 \%$, pada pertanaman kol sebesar 53\%, dan pada pertanaman bawang daun sebesar $51 \%$.

\section{PEMBAHASAN}

Data lingkungan berupa suhu udara, intensitas cahaya, kelembaban udara, dan curah hujan di kedua lahan pertanian, selama pengambilan sampel kumbang tidak menunjukkan perbedaan yang besar (Tabel 1). Jumlah individu dan spesies kumbang di lahan pertanian organik (389 individu, 13 spesies) lebih banyak dibandingkan di lahan pertanian non-organik (221 individu, 10 spesies). Berdasarkan hasil perhitungan,

Tabel 1. Parameter lingkungan di lahan pertanian organik dan non-organik saat pengambilan kumbang

\begin{tabular}{llllll}
\hline Lahan pertanian & Suhu udara $\left({ }^{\circ} \mathrm{C}\right)$ & Intensitas cahaya (Lux) & $\mathrm{rH}(\%)$ & Curah hujan $(\mathrm{mm} / \mathrm{hari})$ & $\mathrm{pH}$ \\
\hline Organik & $26.83(25.4-27.9)$ & $1414.67(1,402-1,429)$ & $63.67(62.2-64.5)$ & $20(4-56)$ & $7(6.9-7.2)$ \\
Non-organik & $25.11(25.3-24.9)$ & $1408.67(1,397-1,420)$ & $64.23(62.8-65.2)$ & $20(4-56)$ & $6.6(6.5-7)$ \\
\hline
\end{tabular}

Nilai merupakan rataan dari pengambilan data lingkungan setiap hari selama pengoleksian sampel, angka di dalam kurung merupakan nilai minimun dan maksimum terukur

Tabel 2. Jumlah individu dan spesies kumbang koprofagus yang dikoleksi dari lahan pertanian organik dan non-organik

\begin{tabular}{|c|c|c|c|c|c|c|c|c|c|c|c|}
\hline \multirow{2}{*}{ Famili (subfamili) spesies } & \multicolumn{5}{|c|}{ Lahan organik } & \multicolumn{5}{|c|}{ Lahan non-organik } & \multirow{2}{*}{$\begin{array}{l}\text { Total } \\
\text { ind. }\end{array}$} \\
\hline & $\mathrm{J}$ & $\mathrm{W}$ & $\mathrm{K}$ & $\mathrm{BD}$ & $\sum$ ind. & $\mathrm{J}$ & W & $\mathrm{K}$ & $\mathrm{BD}$ & $\Sigma$ ind. & \\
\hline \multicolumn{12}{|l|}{ Aphodiidae (Aphodinae) } \\
\hline \multicolumn{6}{|l|}{ Scarabaeidae (Coprinae) } & & 0 & 0 & 0 & 0 & 4 \\
\hline Copris reflexus & 79 & 49 & 35 & 27 & 190 & 22 & 20 & 10 & 7 & 59 & 249 \\
\hline Catharsius mollosus & 0 & 0 & 0 & 0 & 0 & 2 & 4 & 0 & 0 & 6 & 6 \\
\hline Onthopagus trituber & 1 & 0 & 0 & 0 & 1 & 0 & 0 & 0 & 0 & 0 & 1 \\
\hline Onthopagus babirusa & 8 & 3 & 9 & 4 & 24 & 7 & 0 & 0 & 1 & 8 & 32 \\
\hline Onthopagus pauper & 34 & 20 & 35 & 33 & 122 & 32 & 21 & 51 & 13 & 117 & 239 \\
\hline Onthopagus javanus & 0 & 1 & 3 & 1 & 5 & 0 & 0 & 0 & 0 & 0 & 5 \\
\hline Onthopagus lilliputanus & 0 & 4 & 12 & 3 & 19 & 4 & 4 & 1 & 1 & 10 & 29 \\
\hline Onthopagus variolaris & 0 & 1 & 2 & 4 & 7 & 5 & 0 & 0 & 4 & 9 & 16 \\
\hline Onthopagus tricolor & 1 & 3 & 4 & 0 & 8 & 0 & 0 & 0 & 0 & 0 & 8 \\
\hline Onthopagus pygidialis & 0 & 0 & 0 & 0 & 0 & 0 & 0 & 0 & 2 & 2 & 2 \\
\hline Onthopagus deflexicollis & 1 & 0 & 0 & 0 & 1 & 0 & 0 & 4 & 0 & 4 & 5 \\
\hline Onthopagus sp1. & 1 & 2 & 2 & 1 & 6 & 0 & 0 & 0 & 0 & 0 & 6 \\
\hline Onthopagus sp2. & 1 & 0 & 0 & 0 & 1 & 0 & 3 & 0 & 0 & 3 & 4 \\
\hline Onthopagus sp3. & 1 & 0 & 0 & 0 & 1 & 0 & 0 & 3 & 0 & 3 & 4 \\
\hline Total individu & 127 & 85 & 103 & 74 & 389 & 72 & 52 & 69 & 28 & 221 & 610 \\
\hline Total spesies & 8 & 9 & 11 & 8 & 13 & 6 & 5 & 5 & 6 & 10 & 15 \\
\hline $\mathrm{H}^{\prime}$ & 1.12 & 1.32 & 1.66 & 1.39 & 1.4 & 1.4 & 1.33 & 0.85 & 1.4 & 1.42 & \\
\hline E & 0.51 & 0.6 & 0.69 & 0.67 & 0.55 & 0.78 & 0.83 & 0.57 & 0.78 & 0.62 & \\
\hline C & 0.46 & 0.26 & 0.26 & 0.34 & 0.34 & 0.31 & 0.33 & 0.57 & 0.3 & 0.37 & \\
\hline
\end{tabular}



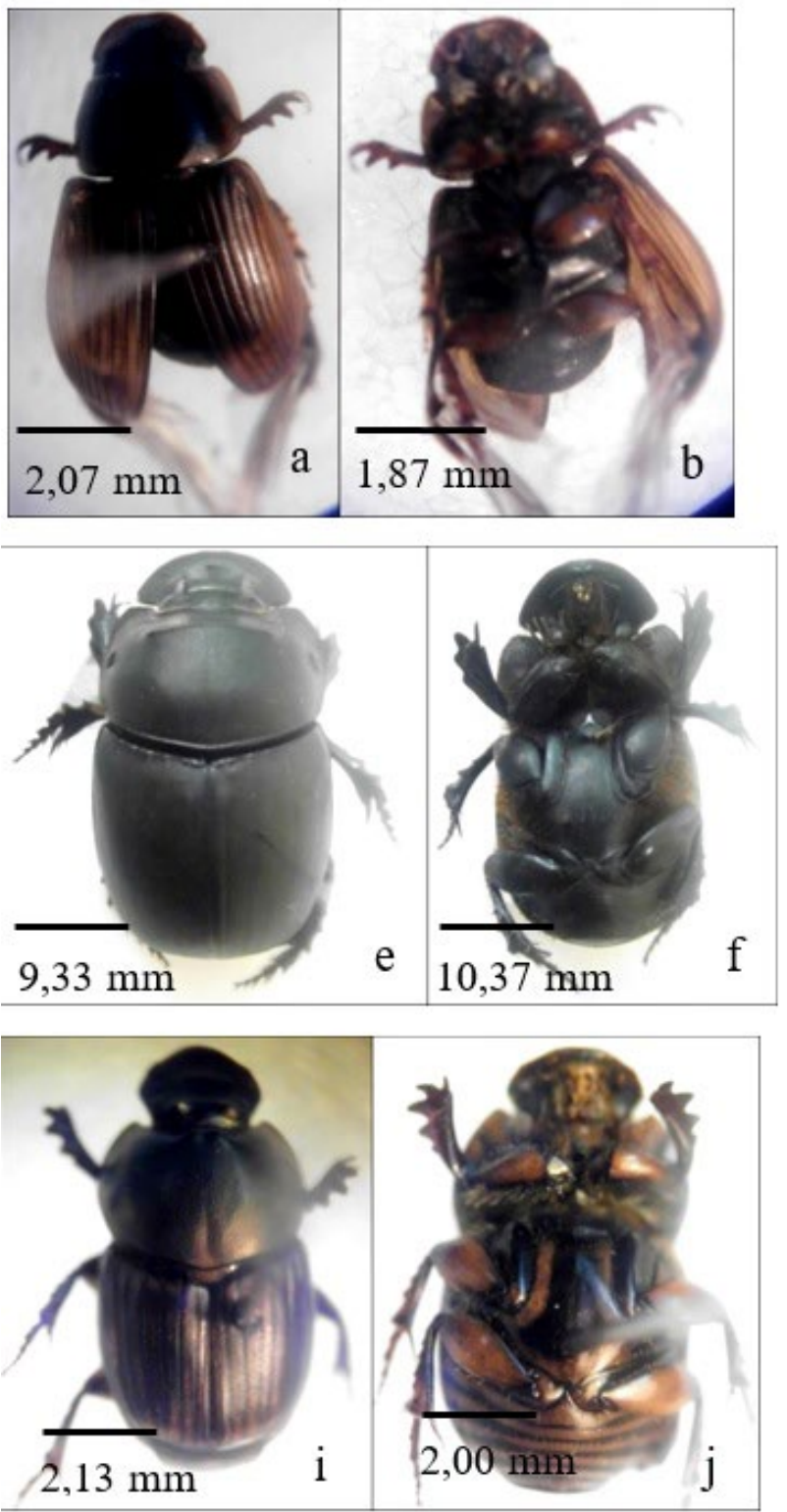

Gambar 1. Kumbang koprofagus di lahan pertanian: Aphodius marginellus $(\mathrm{a}=$ dorsal, $\mathrm{b}=\mathrm{ventral})$, Copris reflexus $(\mathrm{c}=\mathrm{dorsal}$, $\mathrm{d}=$ ventral), Catharsius mollosus ( $\mathrm{e}=\mathrm{dorsal}, \mathrm{f}=\mathrm{ventral})$, Onthopagus trituber $(\mathrm{g}=\mathrm{d}$ orsal, $\mathrm{h}=$ ventral), Onthopagus babirusa $(\mathrm{i}=$ dorsal, $\mathrm{j}=$ ventral $)$, Onthopagus pauper $(\mathrm{k}=$ dorsal, $\mathrm{l}=$ ventral $)$

nilai keanekaragaman kumbang koprofagus di lahan pertanian organik sebesar 1.4 dan di lahan non-organik sebesar 1.42 (Tabel 2). Nilai yang tidak jauh berbeda ini kemungkinan karena pengambilan sampel di kedua lahan pertanian dilakukan pada waktu yang sama dan data lingkungan yang tidak jauh berbeda (Tabel 1). Noerdjito (2009) melaporkan waktu koleksi dan keadaan habitat mempengaruhi keragaman kumbang koprofagus.

Secara umum, di lahan pertanian organik dan nonorganik tidak terjadi dominansi kumbang $(\mathrm{C}<0.5)$. Spesies kumbang yang paling banyak ditemukan pada lahan organik adalah C. reflexus (190 individu) dan O. pauper (122 individu), sedangkan pada lahan non-organik adalah $O$. pauper (117 individu). Pada analisis dominansi pertanaman, di lahan organik dan non-organik tidak terjadi dominansi, kecuali pada
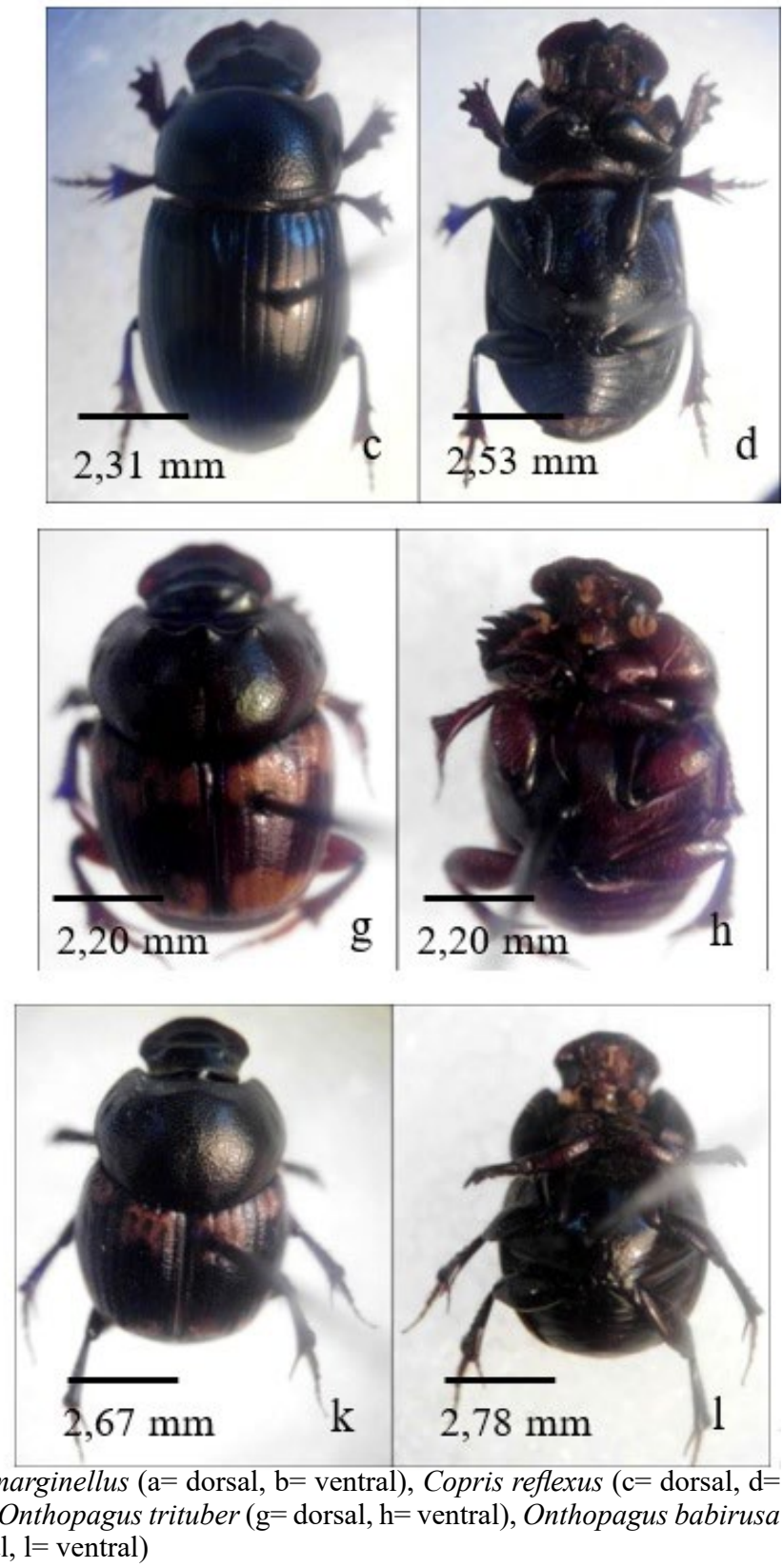

pertanaman kol di lahan non-organik yang memiliki nilai dominansi sebesar 0.57 . Kumbang yang paling banyak ditemukan pada pertanaman kol di lahan nonorganik adalah $O$. pauper (51 individu) (Tabel 2).

Banyaknya pohon dan adanya hutan wisata di dekat lahan pertanian non-organik menjadikan lahan tersebut lebih teduh, sehingga kotoran tidak cepat kering. Kotoran yang lembap lebih disukai oleh kumbang koprofagus (Hanski dan Cambefort 1991). Hutan wisata sebagai habitat satwa, seperti tupai, monyet, dan burung juga mengindikasikan banyaknya kotoran hewan sebagai pakan kumbang koprofagus. Hal ini sesuai dengan laporan Andresen (2003), kumbang koprofagus banyak ditemukan di daerah hutan yang lebih alami dibanding dengan lahan yang sudah terdegradasi. Menurut Hanski dan Cambefort (1991), banyaknya kotoran pada suatu 
daerah akan mempengaruhi keberadaan kumbang koprofagus.

Pada pertanaman jagung di kedua lahan pertanian, paling banyak ditemukan kumbang koprofagus (127 individu di lahan organik dan 72 individu di lahan non-organik). Nilai indeks keanekaragaman kumbang pada pertanaman jagung di lahan pertanian organik ialah 1.12 dan di lahan pertanian non-organik ialah 1.4. Tanaman jagung memiliki daun yang lebar dan jarak tanam yang rapat. Pada pertanaman jagung, juga terdapat gulma. Hal ini membuat lahan pertanaman jagung lebih tertutup dan teduh. Doube (1983) melaporkan bahwa di daerah yang tertutup ditemukan spesies kumbang koprofagus lebih banyak dari pada daerah padang rumput.

Pada pertanaman wortel di lahan organik ditemukan 85 individu (9 spesies) kumbang koprofagus dengan nilai keanekaragaman sebesar 1.32. Di lahan nonorganik ditemukan 52 individu (5 spesies) kumbang koprofagus dengan nilai keanekaragaman 1.33. Pemakaian pupuk dan insektisida di lahan non-organik dapat mempengaruhi kumbang koprofagus.

Keanekaragaman kumbang koprofagus paling tinggi pada pertanaman kol di lahan pertanian organik $\left(H^{\prime}=1.66\right)$ dengan jumlah individu 103. Selain tertarik pada aroma kotoran dari umpan dung trap dan dari pupuk kandang, kumbang koprofagus kemungkinan tertarik aroma khas berupa senyawa sekunder yang dihasilkan tanaman kol. Pemakaian insektisida nabati pada pertanaman kol di lahan organik, kemungkinan tidak mengganggu kehidupan kumbang koprofagus. Pada pertanaman kol di lahan non-organik, nilai keanekaragaman kumbang paling rendah $\left(\mathrm{H}^{\prime}=\right.$ 0.85). Pemberian insektisida pada pertanaman kol dilakukan dengan cara penyemprotan. Tanaman kol yang rendah menyebabkan insektisida yang diberikan dengan penyemprotan mengenai umpan maupun pupuk kandang. Spesies kumbang kotoran yang kuat dan mampu beradaptasi yang dapat ditemukan di lahan nonorganik. Formulasi insektisida tidak berpengaruh besar terhadap kumbang koprofagus, kecuali jika insektisida terkena langsung pada kotoran yang dikonsumsi oleh kumbang koprofagus (Bertone et al. 2004).

Jumlah individu kumbang paling sedikit ditemukan pada pertanaman bawang daun (74 individu di lahan pertanian organik dan 28 individu di lahan pertanian non-organik). Nilai keanekaragaman kumbang pada pertanaman bawang daun di lahan organik dan nonorganik sebesar 1.39 dan 1.40. Jumlah individu yang rendah pada pertanaman bawang daun di lahan non-organik kemungkinan disebabkan pemberian insektisida yang dilakukan dengan penyemprotan. Tanaman bawang daun yang rendah menyebabkan insektisida semprot mengenai kotoran sebagai pakan kumbang koprofagus. Kurangnya daerah naungan di pertanaman bawang daun, menyebabkan kotoran akan lebih cepat kering dan tidak disukai olah kumbang koprofagus.

Onthopagus sp. dan Copris reflexus merupakan kumbang koprofagus tipe tunnelers. (Bertone et al. 2006) melaporkan spesies kumbang tunnelers dapat mempengaruhi siklus nutrisi dan kesuburan tanaman. Perilaku mengambil kotoran, kemudian membenamkan kotoran di dalam terowongan membantu pembusukan dan degradasi kotoran. C. reflexus (panjang 8.1 $\mathrm{mm}$ ) dan $O$. pauper (panjang $6.4 \mathrm{~mm}$ ) merupakan kumbang yang berukuran tubuh besar. Ditemukannya kedua spesies kumbang tersebut di lahan organik mengindikasikan daur materi yang cepat. Pada lahan non-organik, $O$. pauper ditemukan lebih sedikit dibandingkan di lahan organik, tetapi ditemukan juga Catharsius mollosus (6 individu) dengan ukuran tubuh besar $(28 \mathrm{~mm})$, sehingga menunjukkan cepatnya daur hara. Shahabuddin et al. (2008) melaporkan ukuran dan biomassa kumbang lebih berpengaruh dalam proses dekomposisi kotoran dan penyuburan tanah dibandingkan dengan jumlah individu kumbang. Klarifikasi spesies dan biomassa kumbang masih perlu dilakukan untuk dapat menyimpulkan kualitas kesuburan di lahan pertanian organik dan non-organik karena aktivitas kumbang. Setiap spesies kumbang memiliki tingkat kesensitifan terhadap perubahan lingkungan yang berbeda. Sifat ini mempengaruhi kumbang dalam memilih habitat.

Kumbang O.pauper banyak ditemukan di lahan pertanian organik dan non-organik. Hanski dan Cambefort (1991) melaporkan Onthopagus sp. merupakan kumbang yang bersifat universal dan lebih mudah beradaptasi dengan perubahan lingkungan. Kumbang Onthopagus sp. merupakan kumbang tunnelers sehingga lebih banyak ditemukan dalam kotoran. Kumbang tunnelers membuat sarang di dalam terowongan dalam kotoran, sehingga kehidupan kumbang ini tidak terlalu terpengaruh oleh kondisi lingkungan.

Kumbang C. reflexus mempunyai ukuran tubuh relatif besar (panjang $8.1 \mathrm{~mm}$ ). Spesies ini memiliki jumlah individu paling banyak di lahan pertanian organik (190 individu). Pada lahan non-organik hanya ditemukan 59 individu spesies $C$. reflexus. Jankielson et al. (2001) melaporkan kumbang koprofagus dengan ukuran tubuh besar lebih sensitif terhadap perubahan lingkungan. Jumlah individu $C$. reflexus sedikit ditemukan di lahan non-organik. Hal ini kemungkinan karena pengaruh pemberian bahan kimia yang menyebabkan tanah lebih asam (Tabel 1). Tingkat keasaman tanah yang rendah menjadi indikator ketidaksuburan tanah (Yamani 2010).

Kumbang A. marginellus (famili Aphodiidae) hanya ditemukan di lahan organik. Spesies kumbang ini 
bersifat $d$ wellers yang memakan kotoran dan umumnya meletakkan telur di kotoran dan tidak membuat sarang (Hanski dan Cambefort 1991). Kumbang ini memanfaatkan kotoran sebagai tempat hidup larva. Oleh karena itu, kumbang A. marginellus lebih sensitif terhadap perubahan lingkungan. Penggunaan bahan kimia, seperti pupuk dan insektisida, berpengaruh terhadap kumbang Aphodius sp. Bertone et al. (2004) menyatakan kumbang Aphodius sp. merupakan kumbang yang sensitif terhadap perubahan lingkungan.

Di lahan non-organik ditemukan C. mollosus yang memiliki ukuran tubuh paling besar (panjang $28 \mathrm{~mm}$ ) dari semua kumbang koprofagus yang terkoleksi. Keberadaan C. mollosus di lahan pertanian nonorganik kemungkinan karena kumbang tertarik pada pupuk kandang berupa kotoran sapi yang digunakan sebagai pupuk dasar. Kotoran sapi mempunyai ukuran relatif besar, bertekstur halus, dan lebih beraroma dan mengandung mikroba dan nematoda (Vulinuc 2000). Errousi et al. (2004) melaporkan kumbang dengan ukuran besar akan membutuhkan kotoran yang berukuran besar. Adanya hutan wisata kemungkinan menyebabkan ditemukannya kumbang Catharsius sp. di lahan non-organik. Kahono dan Setiadi (2007) melaporkan Catharsius sp. banyak ditemukan di daerah hutan dengan keadaan yang lebih alami dibandingkan dengan lahan yang sudah terdegradasi.

Kesamaan spesies kumbang di lahan organik dan non-organik sebesar 67\%. Indeks kesamaan Sorensen menekankan banyaknya spesies yang ditemukan pada kedua lokasi (Marguran 1988). Kesamaan spesies kumbang paling tinggi pada pertanaman jagung (89\%), diikuti wortel (64\%), kol (53\%), dan bawang daun (51\%). Kesamaan kumbang yang tinggi pada pertanaman jagung kemungkinan disebabkan oleh penggunaan insektisida yang sedikit. Insektisida yang digunakan pada pertanaman jagung di lahan non-organik berbentuk kristal yang diberikan di awal penanaman. Insektisida tersebut ditaburkan di pucuk atau dipendam dalam tanah. Peluang kotoran terkena insektisida lebih kecil, sehingga mengurangi dampaknya terhadap kumbang.

\section{KESIMPULAN}

Jumlah individu dan spesies kumbang koprofagus di lahan organik lebih tinggi (389 individu, 13 spesies) dari pada di lahan non-organik (221 individu, 10 spesies). Di kedua tipe lahan pertanian tersebut tidak terjadi dominansi spesies kumbang. Spesies kumbang yang ditemukan paling banyak di lahan organik adalah $C$. reflexus, sedangkan pada lahan non-organik adalah $O$. pauper. Kesamaan spesies kumbang di lahan organik dan non-organik sebesar $67 \%$.

\section{DAFTAR PUSTAKA}

Andresen E. 2001. Effects of dung presence, dung amount, and secondariy dispersal by dung beetles on the fate of Mycropholis guyanensis (Sapotaceae) seeds in Central Amazonia. J Trop Ecol 17: 61-78.

Andresen E. 2003. Effect of forest fragmentation on dung beetle communities and functional consequences for plant regeneration. Ecography 26:87-97.

Arrow GJ. 1991. The Fauna of British India: Coleoptera. Lamellicornia. New Delhi: Today and Tomorrow's Press.

Balthasar. 1963. Monographie der Scarabaeidae and Aphodiidae der palaearktischen und orientalischen Region. Cekoslowakia: Verlag der Tschechoslowakischen Akademie der Wissenschaften.

Bertone MA, Watson W, Stringham M, Green JT, Steve W, Poore MH, Hucks M. 2004. Dung beetles of Central and Eastern North carolina cattle pastures. North Carolina: NC State University.

Bertone MA, Green JT, Washburn SP, Poore MH, Watson DW. 2006. The contribution of tunneling dung beetles to pasture soil nutrition. North Carolina: NC State University.

Borror DJ, Triplehorn CA, Johnson NF. 1989. An Introduction to the Study of Insects $7^{\text {th }}$ edition. New York: Saunders College Publishing.

Davis AJ, Holloway JD, Huijbregts H, Krikken J, Kirk-Spriggs AH, Sutton S. 2001. Dung beetles as indicators of change in the forests of Northern Borneo. J Appl Ecol 38:593-616.

Doube BM. 1983. Habitat preference of some bovine dung beetles (Coleoptera: Scarabaeide) in Hluhluwe Game Reserva, South Africa. Bull Entomol Resch 73:357-371.

Errouissi FS, Haloti PJ, Robert AJ, Idrissi, Lumaret JP. 2004. Effect of the attictiveneess for dung beetle of dung pat origin and size alog climatic gradient. J Environ Entomol 33:45-53.

Hanski I, Cambefort Y. 1991. Dung Beetle Ecology. Princeton: Princeton University Press.

Hanski I, Krikken J. 1991. Dung beetles in tropical forests in South East Asia. In: Hanski I, Cambefort Y. Dung Beetle Ecology. Princeton: Princeton University Pr. p 179-197.

Jankielson A, Scholtz CH, Louw SVDM. 2001. Effect of habitat transformation on dung beetle assemblages: A comparison between a south african nature reserve and neighboring farms. J Ecol Entomol 30:474-483.

Kahono S, Setiadi LK. 2007. Keragaman dan Distribusi Vertikal Kumbang Kotoran Scarabaeidae (Coleoptera: Scarabaeidae) di Hutan Tropis Basah Pegunungan Taman Nasional Gede Pangrango, Jawa Barat, Indonesia. Biodiversitas 7: 118-122.

Krikken J, Huijbregts J. 2008. Sulawesi large-eyed Onthophagus and their relatives: seven new species with a key (Coleoptera: Scarabaeidae: Scarabaeinae). Tijdschrift voor Entomol 151:155-171.

Marguran AE. 1988. Ecological Diversity and Its Measurement. New Jersey: Princeton University Pr.

Noerdjito WA. 2009. Pengaruh ketinggian dan habitat terhadap keragaman kumbang koprofagus (Coleoptera: Scarabaeidae) di jalur pendakian Apuy dan Linggarjati, Taman Nasional Gunung Ciremai. J Biol Indones 5:295-304.

Shahabuddin, Manuwoto S, Hidayat P, Noerdjito WA, Schulze CH. 2008. The role of coprophagus beetles on dung decomposition and enhancement of soil fertility: effect of body size, species diversity, and biomass. J Biol Indones 5:109-119.

Yamani A. 2010. Kajian tingkat kesuburan tanah pada hutan lindung Gunung Sebatung di Kabupaten Kotabaru. $J$ Hutan Trop 11:32-37

Vulinuc K. 2000. Dung beetle(Coleoptera: Scarabaeidae), monkeys, and conservation in Amazonia. Florida Entomol 83: 229-241. 